\title{
Field and environmental approaches to world politics: implications for data archives ${ }^{1}$
}

\author{
RAYMOND TANTER \\ Department of Political Science, University of Michigan \\ and JAMES N. ROSENAU \\ Department of Political Science, Ohio State University.
}

Negotiations of statesmen might be facilitated if the entire field of international relations were so represented that the negotiator could see the relations of the circles and vectors representing their respective peoples, nations, states, and governments located at particular points in the geographical and analytical fields, and moving in certain directions in the latter. An observer might calculate with less margin of error the probable outcome of such negotiations [Wright, 1955, p. 566].

This quotation from Quincy Wright illustrates his concern for the policy relevance of data on world politics. Wright's dynamic mapping of international relations via his field approach assumes predictive models and quantitative data to be valid for policy purposes. Policy forecasts, moreover, would provide a stringent test of the validity of models and of the reliability of data.

It is precisely the conjunction of his concern with theory-building, quantitative data, and policy relevance that makes Wright's work stand out, that allows it to endure, and that leads all of us who do research in international relations to feel that his passing took from us

\footnotetext{
'The authors gratefully acknowledge the help of Robert Beattie, Hazel Markus, Thomas Sanders, and Stephen Shaffer, and the support of ONR Contract N00014-67-A-0181-0026 ARPA Order \# 1411 for Raymond Tanter and NSF grant GS3117 for James N. Rosenau.
}

the pioneer of modern approaches. Long is the list of scholars who across centuries have propounded models of international phenomena. Still longer is the list of those who have advanced policy relevant prescriptions. And growing even longer is the list of those who generate quantitative data in the field. But short indeed is the roster of scholars in the field who have treated all three activities as but one task. And Quincy Wright leads this short list, partly because he was the first to do it, but mainly because he synthesized the three tasks so well that the singularity of the task is now commonplace.

To be sure, as noted below, Wright did not achieve this synthesis by gathering data to explore his field approach (1955), nor did he achieve it by deriving a general theory of war from his monumental collection of empirical materials on the subject (1942). Yet synthesis need not be attained in a single major work. It can emerge in a lifetime of effort and it is here that, to use David Singer's felicitous phrase, Wright "showed us the way" (1965). He achieved synthesis by devoting his career to both theoretical and empirical investigations, while never ceasing to call attention to their policy implications. If it is now commonplace for the same scholar to succumb to the pressures that his theories exert for data and that 
his data exert for theories, it is because Quincy Wright demonstrated that the same person could and should be a party to all the stages in the endless and exhilarating process of creating valid and useful knowledge.

Indeed, it is this spirit of synthesis that underlies the goals of the present essay. We want to relate the theoretical work of Wright both to that of other theorists and to some of the quantitative data that have been generated in recent years. More specifically, two objectives underlie what follows:

(1) We want to discuss Wright's field approach, especially in comparison with the environmental approach of Harold and Margaret Sprout and to a lesser extent with the approaches of Rudolph Rummel, Charles McClelland, and one of the present authors.

(2) We want to relate quantitative data in one international relations archive to Wright's field approach and to the Sprouts' environmental approach.

\section{Field and Environment}

Both Wright and the Sprouts focus on capabilities and values as twin pillars upon which to construct models of foreign policy behavior and international relations. While Wright suggested that, "The most important information for the decision-maker in international affairs is usually the values and capabilities of the statesmen of other countries" (1955, p. 575), the Sprouts asserted that, "It is utterly meaningless to speak of capabilities in the abstract. Capability is always capability to do something" (1961, p. 117). In short, unless there is some specification of ends and means, no inventory of environmental factors has any significance.

Both the Sprouts and Wright anticipated the acquisition of substantive information, the coding of this information into data, and the testing of implications of their models against data. Indeed, the Sprouts noted that, "With respect to calculation of future changes in the milieu of international politics, the student suffers not from paucity of data but from quantities that threaten to swamp him" (1961, p. 71). Despite the great quantities of information available, however, the Sprouts set forth models that anticipated the need to create new data. Their stress on the psychological environment of decision-makers as distinct from the operational environment in which officials must act amounts to a constant call for the creation of data on perceptions. The great quantity of available information mainly depicts the operational environment and the Sprouts argue, in effect, that such data are not sufficient. They proceed on the assumption that there is a distortion between the world as it is and the world that decision-makers perceive. Hence, there is a need to obtain independent measurements of decision-makers' perceptions and use these in concert with more objective indicators of their operational environment.

Wright also emphasized the need for data to validate his models. Indeed, as already indicated, he devoted considerable energy to information acquisition and data-making. He suggested that information on the values and policies of states should be acquired from biographies of national leaders, from the history of the country, from an analysis of prevailing ideologies, and from deductions using the assumed national interests of states. In addition, Wright acknowledged the need to acquire information on indicators of capabilities of governments as found in their armaments, resources, production, technical personnel, dissident opinions, parties, etc.

Wright assumed that systematic publication of opinion surveys, political developments, and arms acquisition would narrow the range of misinformation and decrease excessive anxieties rising from exaggerated reports. Wright thought that peace depends on a balance of power, and that information about the capabilities of states is important in selecting foreign policies which would preserve the 
balance. He acknowledged that the balance of power could be disturbed by a state which finds that time is running against it on important indicators of capability. Nevertheless, Wright suggested that "This paradoxical situation, in which ignorance of the future may be the best assurance of peace, can only be remedied by better and more generally distributed information on the probable consequences of war . . ." (emphasis added, 1955, pp. 576-77).

Thus it is hardly surprising that in $\boldsymbol{A}$ Study of War (1942), Wright compiled great quantities of statistical information on casualties, population, weather, battles, and technology. Wright also included theoretically interesting quantitative data on the relative distance between pairs of great powers, trends of opinions within the great powers, and estimates of the probability of war. Given his field approach and specific models, Wright's compilation of statistics and creation of data on war yield a body of facts which stands unchallenged as the most significant one collected by an international relations scholar. ${ }^{2}$

Yet, as already implied, in spite of his attention to information and data, Wright devoted little attention to validating the coordinates of his analytic field. He did not, for example, use a dimensional method such as factor analysis to delineate dimensions of capabilities and values. Wright anticipated that other scholars would (1) acquire additional data, (2) validate his a priori specification of the components of the analytic field, and (3) proceed to the estimation of parameters relating field components to such external criteria as warlike and peaceful relations between states. Do Wright's three expectations manifest themselves in the work performed by other scholars? One answer by Charles

'In addition to Wright's compilation there is the data set of J. D. Singer and M. Small. Singer's Wages of War promises to be another trail-blazing contribution to the acquisition and analysis of data on war.
McClelland implies that there has been relatively little progress on these three fronts. McClelland states that:

On the grounds of superior clarity, applicability and continuity, one might have expected that Wright's field theory would have been seized upon by young scholars who were seeking interesting and worthwhile research directions and by theorists who would locate defects and pursue refinements in the conception. ... The intellectual history of the study of international relations during the past fifteen years does not bear out this prediction. The attention has gone to system ideas and approaches [1968, p. 3].

Agreement with McClelland that Wright's work has not been the basis of subsequent research depends upon how one measures Wright's influence. If one measures Wright's influence by the number of scholars who explicitly validate and estimate parameters based on his field approach, Wright has had little influence. ${ }^{3}$ Rudolph Rummel (1965) may be the only major scholar who attempts to validate and estimate parameters by following Wright's initial efforts. For example, Rummel's "social field theory" explicitly uses Wright's ideas as a point of departure, although some slippage between Rummel and Wright has been noted (Lamborn, 1971).

Measuring a theorist's influence by the number of scholars who build directly on his work, however, is only one of several criteria that can be used. As we have already noted, perhaps an equally important criterion for measuring a theorist's influence is the indirect effect he has on the discipline. How many scholars seek to develop the kind of synthesis of knowledge he advocated? How many scholars use general ideas clearly associated with his work? Viewed in the context of these questions, Wright's influence is considerable. One of his central ideas, for example, is that the

'See the following section, Present and Prospective Data for Field/Environment, for a discussion of data based on Wright's ideas. 
attributes of national units should predict to their foreign policy behavior. While this idea did not originate with Wright, he refined the idea by specifying a model linking capabilities and values to warfare. There is much research based upon ideas relating national capabilities to foreign policy behavior (cf. Rummel, 1965; Alker, Russett, 1965). Consider, for example, the following proposition from Rummel regarding Wright's general idea of relating national capabilities to foreign policy behavior. The magnitude of 1955-57 foreign conflict between 91 pairs of nations can be predicted moderately well from the size of the distances between them on dimensions of wealth, joint power, and geography (Rummel, 1965, p. 97).

Similarly, Rummel's dimensions of wealth, joint power, and geography correspond somewhat with Wright's analytical and geographical fields. The capability element of the analytical field incorporates the wealth and power dimensions that Rummel delineates. The geographical field of Wright, however, differs slightly from Rummel's in that only Wright includes permeability of boundaries in addition to geographical distances. ${ }^{4}$ Thus, in addition to building directly on Wright's field approach, Rummel's research is illustrative of Wright's effort to relate national attributes to foreign policy behavior.

McClelland, however, claims that the attempt to use national attributes to predict to international behavior is doomed to failure because of the absence of international system variables. He suggests that international system variables are more adequate than national attributes in explaining international behavior. Field approaches assume that the national attributes additively determine international

\footnotetext{
${ }^{4}$ Distance between nations on dimensions of size and power also might be interpreted according to the geographical field, e.g., distance between nations may refer to the geographical field where nonrelational attributes of nations may refer simply to their analytical capabilities and values.
}

interactions. McClelland, however, suggests that a multiplicative or nonadditive assumption is more plausible than the additive idea. He holds that ". . . complex systems ... seldom if ever have the same characteristies as their constituent components." Specifically, McClelland asserts that the system is not the sum of its parts, a position that places him in conflict with the fundamental proposition of field approaches (1968, p. 11).

Regarding the assumption of additivity in the field approach, consider Wright's capability and value fields. He specifies six concepts within the capability field: (1) flexibilityrigidity; (2) lethargy-energy; (3) strengthweakness; (4) isolation-cooperation; (5) technological advancement-technological backwardness; (6) resource poverty-resource abundance. Moreover, Wright suggests six concepts in the value field: (1) abstractness-concreteness; (2) subjectivity-objectivity; (3) situation orientation-self orientation; (4) restrictiveness-liberality; (5) manipulation-contemplation; (6) negation-affirmation.

Generally, Wright assumes that the capability and value fields have an additive, i.e., independent, effect on war. ${ }^{5}$ Figure 1 is an illustration of Wright's general model relating the capability and value concepts to warfare. The absence of a link between the capability and value concepts indicates that they have an independent (additive) effect on international behavior. This assumption of additivity may be the case only when one considers the analytic field without regard for the geographical field. Wright did not explicate the geographi-

'From Wright's diagram (1955, p. 564) one can infer 36 possibilities for the capability and value concepts to combine two at a time in determining war, though Wright specifies only two direct valuecapability combinations. Wright, however, also states that ". . . values influence capabilities and vice versa" (Wright, 1955, p. 546), which seems inconsistent with his diagram of the value-capability concepts summarized in Figure 1. 


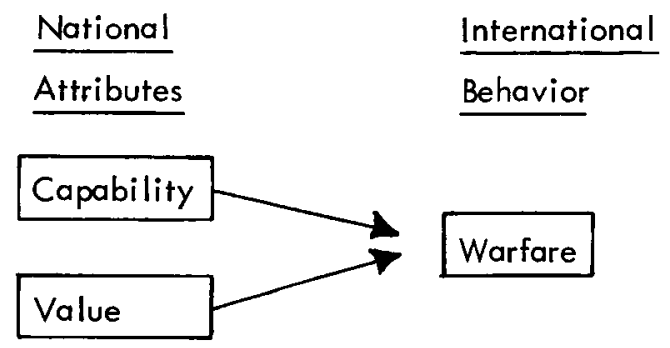

FIG. 1. Wright's general model relating the capability and value concepts to warfare.

cal as adequately as the analytical field; he did include, however, distance between nations in space and distance between nations on other salient dimensions of the geographical field. Wright implied a multiplicative model regarding the geographical field when he suggested that large psychological distance in combination with close physical proximity may yield conflictive interactions.

Consider Figure 2 as a reformulation of Wright's general model-that takes into account the geographical field. That is, the geographical field modifies the relationship between the analytical field and international behavior. The reformulation implies a multiplicative combination of the analytical and geographical field. McClelland, for example, interprets Wright's specification of two fields as suggesting that international processes in the analytical field, such as arms races between nations, need to be considered in the context of their particular ecologies-their geographical fields. That is, warfare between two states may be a consequence of their changing capabilities (arms) as modified by their changing perceptions (psychological distance).

The interpretation of Wright's analytical

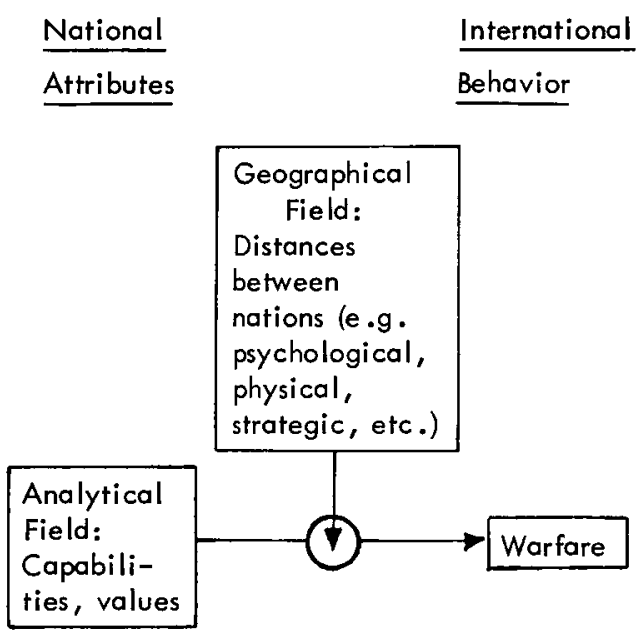

FIG. 2. Wright's general model including the geographical field. 


\section{National-International}

International

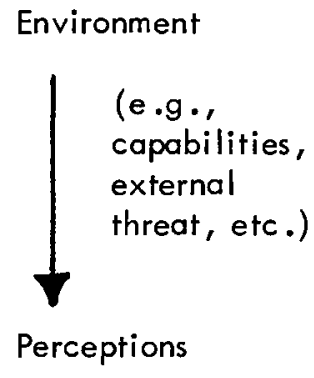

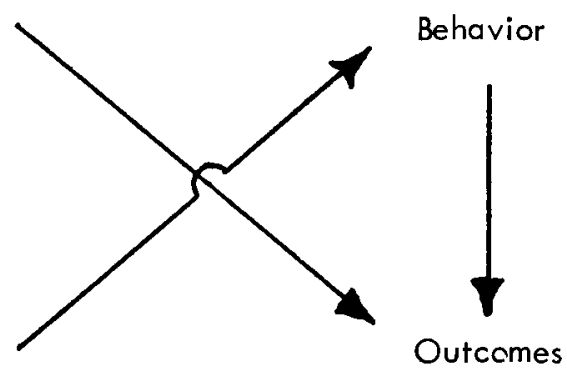

(e.g., of capabilities, external threat, etc.)

FIG. 3. The Sprout model.

field as being modified by the geographical field to affect international behavior approximates the model of Harold and Margaret Sprout; illustrated in Figure 3. The environment of the Sprout's model subsumes Wright's geographical field; perceptions, on the other hand, would be a part of Wright's analytical field. International behavior for the Sprouts is not a direct consequence of the environmental capabilities or external threat; rather, international behavior stems from the perception of the environmental factors. Since perceptions intervene between behavior and the environment, this suggests a multiplicative rather than an additive model. That is, the environmental and perceptual variables do not independently affect behavior. On the contrary, consistent with Wright's model, environmental variables only assume importance in the context of perceptual conditions.

Note that the Sprout model explicitly includes international factors as a part of the environment and perceptions of decisionmakers. Thus perception of external threat is a variable which fits nicely within the Sprouts' model. Though the Sprouts do not specifically consider international system conditions as a part of the environment, their model can be modified easily to take into account systemic structure and processes as suggested by McClelland's approach.

A pre-theory of foreign policy behavior developed by one of the present authors (Rosenau, 1966) may provide a partial synthesis of Wright and the Sprouts and a good transition to McClelland's system approach. The pre-theory allows for the penetration of a polity by international system forces. By incorporating international system conditions, the pre-theory draws on the Sprouts' work. By allowing for the penetration of a polity, the pre-theory is consistent with Wright's interpretation of the geographical field as including permeable national boundaries. The pre-theory, in effect, combines elements of Wright's geographical and analytical fields with the Sprouts' environmental and perceptual factors. It combines these elements in a multiplicative fashion consistent with Wright and the Sprouts. The pre-theory, for example, proposes that foreign policy behavior in small, less developed, closed polities is a consequence of the following determinants in this ordering: international system, idiosyncratic, role, societal, and governmental.

The size, wealth, and political system indi- 
cators proposed by the pre-theory would be subsumed under Wright's analytical field. The links between the indicators are multiplicative for the pre-theory but probably additive within the analytical field. The pre-theory, moreover, specifies that the ordering of the five determinants of foreign policy behavior changes as a consequence of the particular combination of the intervening variablessize, wealth, and political system. This specification of the pre-theory is consistent with but more complex than the Sprout idea of a nonadditive model. A final point of similarity across the three approaches is that the pretheory's stress on idiosyncratic and role variables compares both with the Sprout focus on perception and with Wright's analytical field.

\section{Present and Prospective Data on}

\section{Field/Environment}

Whatever is the capacity of the pre-theory to facilitate a synthesis of the Wright and Sprout models, there remains the question of the availability of data necessary to probe them, either separately or in some synthesized form. The attempt to elaborate or synthesize models without recourse to empirical materials may result in endless wheel-spinning. And thus it is to the second goal of the essay to which we now turn, namely, to relate quantitative data in one international relations archive to Wright's field and to the Sprout's environmental approach. ${ }^{6}$ This section considers the capability concept of Wright and of the Sprouts in relation to archival holdings. Secondly, the section describes deficiencies in the

\footnotetext{
${ }^{5}$ The archive is the International Relations Archive (IRA), Box 1248, Ann Arbor, Michigan 48106. Acknowledgments go to the assistant director of IRA, Robert Beattie, for assistance with this section. The present authors also are related to the IRA as former director (Tanter) and present chairman of the IRA Advisory Committee (Rosenau). See the appendix to this article for listing of the bodies of data now included in this archive.
}

holdings, given the theoretical models of Wright and the Sprouts regarding their value and perception concepts respectively.

While the geographical field locates nations in time and space, the analytical field implies that each international organization, national government, or decision-maker may be located in a multidimensional field. Such a field may be defined by analytical coordinates, each of which indexes a political, economic, or other continuum influencing international actions. Factors in the geographical field are of secondary importance for understanding the actions. Recall that changes in geographical or environmental factors do not directly account for international actions, but these tend to influence such actions by modifying sentiments, values, goals, and beliefs in the minds of decision-makers (Wright, 1955, p. 542).

Since Wright did not explicate the geographical field adequately, the following discussion only considers the analytical field, with special reference to capabilities. The International Relations Archive (IRA) has some variables which are indicators of value, but these are limited to a few content analyses for the People's Republic of China, the USSR, and the United States (Mogdis and Tidwell, in appendix). On the other hand, most concepts in the capability field of Wright and in the environment of the Sprouts have indicators in the IRA. Table 1 presents a matrix containing indicators of capability, and draws only illustratively from the archive since IRA has too many capability-type variables to list. Those listed in the table stem from the indicators Wright himself suggests (1955, pp. 595-601). The rows of the matrix are the six capability coordinates; the column headings designate what Wright calls levels at which collective systems of action function (p. 556).

Following Wright's classification, primary entities in international relations are the sovereign states. Each sovereign state has four components. The term people includes the 
TABLE 1

CAPABILITY INDICATORS*

\begin{tabular}{|c|c|c|c|c|}
\hline ENTITIES: & People & Nation & State & Government \\
\hline Energy-Lethargy & $\begin{array}{l}\text { GNP/capita: } \\
\text { Banks and Textor } \\
\text { Taylor and Hudson } a \\
\text { Rummel } b \\
\text { Banks } a \\
\text { Income/capita: } \\
\text { Gurr } \\
\text { Rummel } b\end{array}$ & $* *$ & $\begin{array}{l}\text { National income: } \\
\text { Rummel } b \\
\text { Banks } a\end{array}$ & $\begin{array}{l}\text { Government expenditure: } \\
\text { Russett el al. } \\
\text { Rummel } b \\
\text { Banks } a\end{array}$ \\
\hline Flexibility-Rigidity & $\begin{array}{l}\text { Group discrimination: } \\
\text { Gurr } \\
\text { Internal security } \\
\text { forces: } \\
\text { Taylor and Hudson a }\end{array}$ & $\begin{array}{l}\text { Press freedom and } \\
\text { censorship: } \\
\text { Rummel } b \\
\text { Taylor and Hudson } a \\
\text { Banks and Textor }\end{array}$ & $\begin{array}{l}\text { Political centraliza- } \\
\text { tion: } \\
\text { Rummel } b\end{array}$ & $\begin{array}{l}\text { Interest articulation } \\
\text { (various): } \\
\text { Banks and Textor }\end{array}$ \\
\hline Cooperation-Isolation & $\begin{array}{l}\text { International trade: } \\
\text { Rummel } b \\
\text { Russett } \text { et } a l \text {. } \\
\text { Russett } \\
\text { Taylor and Hudson a }\end{array}$ & $\begin{array}{l}\text { International letters } \\
\text { per capita: } \\
\text { Taylor and Hudson } a \\
\text { Rummel } b \\
\text { Banks } a\end{array}$ & $\begin{array}{l}\text { Trade as percent } \\
\text { of GNP: } \\
\text { Taylor and Hudson a }\end{array}$ & $\begin{array}{l}\text { Intergovernmental or- } \\
\text { ganization membership: } \\
\text { Rummel } b \\
\text { Taylor and Hudson } a\end{array}$ \\
\hline Strength-Weakness & $* * *$ & $\begin{array}{l}\text { Energy production: } \\
\text { Rummel } b \\
\text { Population: } \\
\text { Banks and Textor } \\
\text { Taylor and Hudson } a \\
\text { Rummel } b \\
\end{array}$ & $\begin{array}{l}\text { Coastline length: } \\
\text { Rummel } b \\
\text { Military forces: } \\
\text { Taylor and Hudson } a \\
\text { Rummel } b\end{array}$ & $\begin{array}{l}\text { Defense expenditure as } \\
\text { percent of } G N P \text { : } \\
\text { Russett } \text { et al. } \\
\text { Taylor and Hudson } a \\
\text { Rummel } b \\
\text { Banks } a\end{array}$ \\
\hline $\begin{array}{l}\text { Resource } \\
\text { Abundance-Poverty }\end{array}$ & $\begin{array}{l}\text { Area: } \\
\text { Russett et al. } \\
\text { Rummel } b \\
\text { Banks and Textor } \\
\text { Taylor and Hudson } a \\
\text { Banks } a \\
\text { Energy resources } \\
\text { per capita: } \\
\text { Rummel } b\end{array}$ & $\begin{array}{l}\text { Education (at various } \\
\text { levels): } \\
\text { Taylor and Hudson } a \\
\text { Russett } \text { et al. } \\
\text { Rummel } b\end{array}$ & $\begin{array}{l}\text { Potential energy } \\
\text { resources: } \\
\text { Rummel } b\end{array}$ & $\begin{array}{l}\text { Energy production per } \\
\text { capisa: } \\
\text { Rummel } b \\
\text { Banks } a\end{array}$ \\
\hline $\begin{array}{l}\text { Technological } \\
\text { Advancement }\end{array}$ & $\begin{array}{l}\text { Education (at secon- } \\
\text { dary and higher } \\
\text { levels): } \\
\text { Taylor and Hudson a } \\
\text { Rummel } b\end{array}$ & $\begin{array}{l}\text { Book titles published } \\
\text { in pure and applied } \\
\text { science: } \\
\text { Rummel } b \\
\text { Scientific journals: } \\
\text { Taylor and Hudson } a\end{array}$ & $* * * *$ & $* * * * *$ \\
\hline
\end{tabular}

* References in this table are to items in the Appendix rather than to those in the Reference section.

**The IRA presently has no indicator for this cell. Wright suggests "income of the literates."

***No indicator for this cell. Wright suggests "patriotism."

****No indicator for this cell. Wright suggests "utilization of advanced technology in the economy."

*****No indicator for this cell. Wright suggests "official government policy toward technology." 
entire population who feel the effects of major policy decisions. The people exert only a passive influence upon policy through the attitudes which they vaguely manifest as those effects are pleasant or unpleasant. The term nation includes only those members of the population who are aware of the values implicit in the national culture and character and who influence those values by their communications with one another. The word state includes that portion of the population which by voting or other direct participation in politics influences government policy. The word government includes not only the official decision-makers in legislative, executive, and judicial branches of the government, but also the governing elite comprising those who advise and influence decision-makers directly (Wright, 1955, pp. 557-58).

It can be seen that of the twenty-four cells in the matrix all but three have at least one variable in the archive. There are about 500 indicators in the archive that might be used to index concepts in Wright's capability field or in the Sprout's environmental space. The Sprouts asserted, however, that it is not meaningful to speak of capabilities without a specification of ends - that unless there is a statement of values or policies, no inventory of environmental indicators has any significance. Accordingly, capability indicators in IRA are of little use without statements of values and policies. In short, the IRA contains more data for Wright's capability than for his value indicators. With respect to the Sprouts, moreover, the IRA has more data on the environment and less data on perceptions. If one uses the Wright and Sprout models as guides, they suggest the creation of additional data on values and perceptions.

Regarding value, consider the policy statements of national leaders, their biographies, and the ideological predispositions of their peoples. For example, sources of policy data for the United States are the Democratic and Republican presidential nomination accep- tance speeches. One study, in fact, drew on the official proceedings of the Democratic and Republican national conventions for 1928 through 1960, as well as the New York Times for 1964, to perform a content analysis of twenty presidential nomination acceptance speeches. Several of the variables used in the study resemble the concepts Wright specified for his value field (cf. Smith, Stone, and Glenn, 1966, pp. 387-90). A further source of data on the value field or for psychological distance in the geographical field are elite editorial comments. One study, for example, considered the question of whether political integration increased or declined in the Atlantic community over a decade. Specifically, the authors measured trends of elite orientations in the editorials of prestige newspapers in England, France, West Germany, and the United States (Namenwirth and Brewer, 1966).

Additional sources of data on elite perception are the speeches of decision-makers. For example, one study builds on the Sprout idea regarding the impact of distorted images on international conflict and relates perceptions of the environment to international behavior. Specifically, the study performs a content analysis of the speeches of John F. Dulles to obtain his perceptions of the Soviet Union from 1953-1959. The study creates data on Dulles' perception of Soviet capabilities, hostility, and success and Dulles' general evaluation of the Soviet Union (Holsti, 1962; also cf. Holsti, Brody, and North, 1964; Holsti, 1969).

Although there has been a series of content analysis studies to create data on value and perceptions, these have not generated a great quantity of data for use by other scholars. One reason is their high cost as opposed to

\footnotetext{
'Wright also acknowledged the danger of distorted images regarding international conflict behavior.
} 
alternative strategies (cf. Jervis, 1969, and North, 1969, regarding contrasting appraisals of the cost of content data). The cost of content data, however, may be small in relation to the benefits in helping to validate models such as those of Wright and the Sprouts. In addition, the content data could be used as a part of a multiple strategy where aggregate, survey, and content analysis data complement each other (cf. Deutsch, 1966; Webb et al; 1966).

Finally, another body of data regarding the environment is the international system indicators suggested by McClelland as being of more theoretical interest than the indicators of the field approach. The IRA has more systemic than perceptual data, as illustrated by the alliance data of Singer's Correlates of War project, but IRA could use more system level data. International system data less frequently found in the archive concern the penetration of countries by international forces. There are some data available on military intervention, however, in the World Handbook $I I$ (Taylor and Hudson, item $d$ in the appendix) as well as data on economic and military assistance.

As stated previously, Wright's work acknowledges but does not emphasize international system concepts. On the other hand, the Sprouts devote more attention to international system in their environmental concept. Neither Wright nor the Sprouts, however, give the attention to systemic forces that McClelland correctly suggests should be the case. Nevertheless, the field and environment concepts have been useful guides for information acquisition and data-making in world politics. The creation of additional data on perceptions and psychological distances, moreover, might facilitiate the validation of the models of such theorists as Wright and the Sprouts, and the validation of the models should increase their policy relevance. Thus theory building, data acquisition, and policy prescription would proceed along the pathways charted by Quincy Wright. ${ }^{8}$

\section{APPENDIX}

STUDIES AVAILABLE FROM THE

INTERNATIONAL RELATIONS ARCHIVE (I97I)

Alger, Chadwick E., United Nations Interaction. Data on interactions between UN delegates. The data were generated by direct observation of the meetings of the Administrative and Budgetary (Fifth) Committee of the General Assembly during the Seventeenth Regular Session (1962). The unit of analysis is the UN member-country as represented by its delegates. Seventy-one variables have been coded for each country-delegate and his interactions so as to enable analysis such as: the relation of interaction to the legislative process, the interactions of individual nations, the relation between non-committee roles of individuals and voting, regional group interaction, etc.

Banks, Arthur S. (a), Cross-Polity Time Series. Time series data on 153 independent nations. There are 102 variables aggregated by year. Thirty-three variables are coded for the period 1815-1966; the remaining variables are coded for more limited time periods. Demographic, socioeconomic, and political attribute data are included. Data are published in Arthur Banks, Cross-Polity Time Series, (Cambridge, Mass.: MIT Press, 1971).

Banks, Arthur S. (b), Domestic Conflict Behavior. Domestic conflict data on 111 countries. Data were collected for the years 1919-1939 and 1946-1966 on eight conflict variables. The study by Rummel and Tanter below uses the same variables except domestic deaths is omitted. Data exist for 42 years on 52 countries and there are data for less than 42 years on 59 countries.

Banks, Arthur S., and Robert B. Textor, Cross Polity Survey. Data for 115 polities. The independent polity is the unit of analysis, and each is classified according to two sets of variables: "raw character-

${ }^{*}$ The International Relations Archive Advisory Committee (IRAAC) welcomes suggestions on new data sets for IRA. (The appendix contains a list of data sets now in IRA.) Please write to suggest data sets for generation or acquisition: IRA, Box 1248 , Ann Arbor, Michigan 48106. 
istics" and "finished characteristics." The raw characteristics include measures such as population, as well as more subjective measures, such as degree of political modernization and interest articulation. The finished characteristics are dichotomous variables which contrast groups of polities in various ways. Each polity is classified on one side or another of each dichotomy. The data were originally published in Arthur S. Banks and Robert B. Textor, A Cross-Polity Survey (Cambridge, Mass.: MIT Press, 1963).

Bleicher, Samuel A., Computer Analysis of General Assembly Resolutions. Data on 2,370 UN resolutions. The unit of analysis is the resolution, and the data are a content analysis of General Assembly resolutions from 1946 to 1968 . Items such as operative words, organizations mentioned, committee source, and prior resolutions cited are coded. Data sources were the United Nations General Assembly Official Records.

Cady, Richard, and William Prince, Conflict Data. Data for 323 conflicts. These data were supplied by the Office of National Security Studies, Bendix Aerospace Systems Division. The data set contains information on political conflicts during the period 1944 to 1966. For each conflict, the variables include measures of duration, the type of military operations, the type of conflict, the method of termination, and the outcome with regard to the United States.

Cady, Richard, Franz Mogdis, and Karen Tidwell, Major Power Interactions with Less Developed Countries. Data for 90 less developed countries. These data were supplied by the Office of National Security Studies, Bendix Aerospace Systems Division. The data set contains selected interactions of the United States, the Soviet Union, the People's Republic of China, and Eastern European countries with the less developed countries. The overall time span for the data is from 1956 to 1965 . The selected national attributes are recorded yearly for this period, while the major power interactions are recorded for 1959, 1961, 1963, and 1965. The national attributes include such measures as imports and exports, diplomatic representation, visits, and communication rates. The interactions include such measures as proportions of imports from and exports to the major powers, diplomatic recognition, and foreign news service operation.

Coplin, William D., and J. Martin Rochester, Dyadic Disputes. Data for two basic units of analysis: 71 nations and 96 cases. This study provides data to compare and analyze the Permanent Court of International Justice, International Court of
Justice, League of Nations, and United Nations in the international bargaining process. Data are included for all disputes: (1) which occurred between 1920 and 1968; (2) which were dyadic, i.e., in which only two states were directly involved; and (3) which were considered in at least one of the four institutions. Nation-unit data are divided into national attributes of participants and patterns of institutional usage by participants. Case-unit data include case attributes and attributes of the dyadic relationship between the two participants in each case.

Feierabend, Ivo K., Rosalind Feierabend, and Betty Nesvold, Political Events Project. Data on 7,000 events for 84 countries. This study is concerned with the amount of conflict directed by groups and individuals in the prevailing political system against other groups or persons. The data cover the interval, 1948-1965. Twenty-eight categories are used to classify the events. The study provides a conflict intensity rating for each event. The data sources were the Encyclopedia Britannica Yearbook and Deadline Data on World Affairs. An additional data set is being prepared from the New York Times for the period 1955-1964.

Gurr, Ted, Genesis of Civil Violence Project. Data for 114 nations. This study consists of aggregate data on indicators of civil violence and its predictors. Nations have also been categorized into four clusters, originally based on a factor analysis, including political, sociocultural, technological development, and size of population and production center clusters.

Haas, Michael, International Subsystems. Data for subsystems, member nations, wars, and alliances for 1649-1963. The first of four files in this collection consists of data on wars involving subsystem members. The data are derived from Lewis Richardson's Statistics of Deadly Quarrels, Quincy Wright's A Study of War, J. David Singer's Wages of War. Pitrim A. Sorokin's Social and Cultural Dynamics. The second file contains attribute data for the 21 subsystems, e.g., number of new inter-governmental organizations formed, and the number of major power memberships. A third file contains data for the 457 members, e.g., status of the nation in the subsystem and belligerency status of the nations. Finally, there is a data file on alliances involving the subsystem members, e.g., type of alliances, number of major, middle, or minor powers in the alliance, and the locus of the alliance.

Jacobson, Harold K., The United Nations and 
Colonialism. Data on 1,166 UN roll calls. The unit of analysis is the UN roll call, specifically, any roll call from 1946 to 1967 concerned with the issue of colonialism. The data contain information about each roll call and the voting record of UN member-countries on each roll call. Data sources were the United Nations General Assembly Official Records. Data are in vote format. That is, the roll call vote is the case; the member and other descriptive information are the variables. In contrast, the UN Roll Call Data study below has the member as the case and the roll call as the variable.

McClelland, Charles, World Event/Interaction Survey (WEIS). Data for 23,000 events. Each case in the data is a report of an international event. An event/interaction refers to words and deeds communicated between nations, such as threats of military force between nations. The IRA has the WEIS data from January 1966 through August 1969. The data and source of each item is included in the analytic deck. Also included is a descriptive deck which is a complete set of textual descriptions for each event which can be associated with the analytic codings by an event serial number within a year. IRA can supply two FORTRAN programs which can aggregate the daily data into other groupings, e.g., frequencies of action by one nation toward another on a month by month basis can be calculated. These two programs were written for the WEIS project by Clarence Bradford.

Mogdis, Franz, and Karen Tidwell, Sino-Soviet Interaction, A Quantitative Assessment. Data for two nations, the Soviet Union and China. This study consists of an aggregate data set and a perception data set. The aggregate data set covers the period 1950-1967 and includes the following variables: exports, imports, population, and treaties. Foreign aid granted by the Soviet Union and China to selected countries is also included for the years 1959-1967. The perception data set consists of information obtained by content analysis utilizing Inquirer II (a computer program). Selected official statements and newspaper content were analyzed for the period 1950-1967. Soviet and Chinese perceptions of each other and of the United States are coded as follows: strong, weak, active, passsive, negative, and theatening. Each of these perceptions is presented in the original and weighted forms. Data were supplied by the Office of National Security Studies, Bendix Aerospace Systems Division.

Richardson, Lewis Fry, Statistics of Deadly Quar- rels. Data for 779 quarrels. These data, supplied by Rudolph Rummel, cover the time period from 1809 to 1949 . A quarrel involves a pair of opponents and must result in more than 315 human deaths. The magnitude of a quarrel is measured by the logarithm of the number of deaths. The range of magnitudes in the study is from 2.50 to 7.50 , the latter figure for nations involved in World War II. Each quarrel is identified by its beginning date and magnitude. For each quarrel, the nominal variables include the type of quarrel, as well as political, cultural, and economic similarities and dissimilarities between the pairs of combatants. The data were originally published in Lewis Fry Richardson, The Statistics of Deadly Quarrels (Chicago: Quadrangle, 1960).

Rummel, Rudolph J. (a), Foreign Conflict Behavior. Approximately 11,000 events such as border clashes and threats on over 30 descriptive variables for 82 nations. The sources of the data as well as measures of its reliability have also been coded. The periods of time covered include 1955 1962-1965, and the first four months of 1966, with additional time spans to be added as the data become available.

Rummel, Rudolph J. (b), Dimensionality of Nations. Raw data for 82 nations. The 332 variables are grouped into 51 domains. The domains represent cultural, social, agricultural, demographic, and other descriptive categories. Data are generally for 1955.

Rummel, Rudolph J., and Raymond Tanter, Dimensions of Conflict Behavior Within and Between Nations, 1955-1960. Data for 86 countries. This data collection is the product of two separate studies conducted by Rudolph $\mathbf{J}$. Rummel and Raymond Tanter utilizing identical variables for the time periods 1955-1957 and 1958-1960, respectively. These variables are domestic conflict behavior such as riots, coups, and foreign conflict behavior such as protests and threats.

Russett, Bruce M., International Regions and the International System. Data on eighteen separate files which contain the results of Russett's analysis. In particular, the study contains data on regions of social and cultural homogeneity, regions with similar political attitudes on external behavior (measured by UN voting), regions of political interdependence (bound by international organization), regions of economic interdependence (measured by intra-regional trade as a proportion of the nations' national income), and regions of geographical proximity. 
Russett, Bruce M., Karl Deutsch, Hayward Alker, and Harold Lasswell, World Handbook of Political and Social Indicators. Data for 141 polities. The information collected in this study is aggregate data at the national level. Sources are United Nations reports, official publications of national governments, special studies, monographs, and other work by scholars and nongovernmental research organizations. Data were originally published in Bruce M. Russett et al., World Handbook of Political and Social Indicators (New Haven: Yale University Press, 1964).

Singer, J. David, and Melvin Small, The Wages of War. Data for 93 interstate, imperial, and colonial wars dating from 1816 through 1965 . Wars which did not involve at least one interstate system member or which were civil or internal were eliminated. Variables include the beginning and ending dates of the war to calculate nationmonths or magnitude; battle deaths to determine severity of war; as well as several derived ratiobased indicators of intensity. Many measures were converted to annual indicators for each year. Data were also collected for independent and intervening variables such as attributes of the international system and pairwise relationships among warring nations. The data are grouped into four files. Each file contains data for one of the following units of analysis: nations, nationwars, pairs of nations, and wars. The data will be published in J. David Singer and Melvin Small, The Wages of War, 1816-1965: A Statistical Handbook (New York: Wiley, forthcoming).

Taylor, Charles L., and Michael C. Hudson, World Handbook of Political and Social Indicators, II. Data for 136 polities. The data were collected by the World Data Analysis Program of Yale University. This study contains data at points in time between 1948-1967. The data are grouped into four files, each of which might be considered a data set by itself. (a) File 1 is an aggregate data set of population, communication, education, culture, economic, and political variables for the four base dates: 1950, 1955, 1960, and 1965. Data for 1965 are about 90 percent complete, but the proportion of missing data is much higher for the three earlier dates. (b) File 2 consists of annual aggregations, 1948-1967, of eighteen political events such as riots and irregular power changes. (c) File 3 contains daily observations on the event series for each country during the years 1948-1967. This file contains 57,256 recordsone for each daily event. (d) File 4 contains intervention data by date of report. There is one rec- ord per event, a total of 1073 records for the 136 countries. This file contains information about the intervention such as the intervening country, the type of intervention, bloc membership, type of military force used, and amount of military force used.

United Nations Roll Call Data. General Assembly roll calls for the First to the Twenty-third Plenary Sessions (1945-1968), for the First to the Fifth Special Sessions, and for the seven Committees. The collection will be updated through the Twenty-fourth Session (1969) in 1971 and may be continuously updated thereafter. Portions of the roll call collections were archived from two different sources. The First to the Seventeenth Sessions, the First to Fourth Special Sessions, and the First to Fourth Emergency Special Sessions were received from Charles Wrigley of Michigan State University. The data for all subsequent Plenary sessions and for the committees were coded and processed by the International Relations Archive. All of the data are stored in member format. That is, the UN member is the case, the roll call is the variable, and the member's vote is the value for each variable. The codebook contains a synopsis of each role call including the total vote on that roll call and its location in the General Assembly Official Records.

\section{REFERENCES}

Alker, Hayward, and Bruce Russett. World Politics in the General Assembly. New Haven: Yale University Press, 1965.

Deutsch, Karl W. Recent trends in research methods in political science. In James Charlesworth (ed.), A Design for Political Science. Philadelphia: American Academy of Political and Social Science (December, 1966), pp. 149-78.

Holsti, Ole R. The belief system and national images: a case study, Journal of Conflict Resolution. 1962, 6 (Sept.), 244-52.

- Content Analysis for the Social Sciences and Humanities. Reading, Mass.: Addison-Wesley, 1969.

Holsti, Ole R., Richard Brody, and Robert North. Measuring affect and action in international reaction models: empirical materials from the 1962 Cuban Crisis, Journal of Peace Research. 1964, I, 170-89.

Jervis, Robert. The costs of the quantitative study of international relations. In Klaus Knorr and James N. Rosenau (eds.), Contending Approaches 
to International Politics. Princeton: Princeton University Press, 1969, pp. 177-217.

Lamborn, Alan. Wright, Rummel and Lewin: field theoretic approaches in political science and social psychology. Ann Arbor: University of Michigan, Department of Political Science, 1971, mimeo.

McClelland, Charles A. Field theory and system theory in international politics. University of Southern California (June 1968), mimeo., 25 pp.

Namenwirth, J. Z., and Thomas L. Brewer. Elite editorial comment on the European and Atlantic communities in four countries. In Philip J. Stone et al. (eds.), The General Inquirer. Cambridge: MIT Press, 1966, pp. 401-29.

North, Robert C. Research pluralism and the international elephant. In Klaus Knorr and James $\mathbf{N}$. Rosenau (eds.), Contending Approaches to International Politics. Princeton: Princeton University Press, 1969, pp. 218-42.

Rosenau, James N. Pre-theories and theories of foreign policy. In R. B. Farrell (ed.), Approaches to Comparative and International Politics. Evanston: Northwestern University Press, 1966, pp. 5271 .

Rummel, Rudolph. A field theory of social action with application to conflict within nations, General Systems Yearbook, 1965, pp. 183211.

Singer, J. D. (ed.). Human Behavior and International Politics: Contributions from the Social-
Psychological Sciences. Chicago: Rand McNally, 1965.

Smith, M. S., et al. A content analysis of twenty presidential nomination acceptance speeches. In Philip J. Stone et al. (eds.), The General Inquirer. Cambridge: MIT Press, 1966, pp. 359-400.

Sprout, Harold, and Margaret S. Sprout. Environmental factors in the study of international politics. In James N. Rosenau (ed.), International Politics and Foreign Policy: A Reader in Research and Theory. Glencoe, Illinois: Free Press, 1961, pp. 106119.

Tanter, Raymond. Dimensions of conflict behavior within and between nations, 1958-1960, Journal of Conflict Resolution. 1966, 10 (March), 41-65.

Webb, E. J., et al. Unobtrusive Measures. Chicago: Rand McNally, 1966.

Wilkenfeld, Jonathan. Domestic and foreign conflict behavior of nations, Journal of Peace Research, 1968, 5, 57-68.

Wright, Quincy. A Study of War. Chicago: University of Chicago Press, 1942, 1965.

- The Study of International Relations. New York: Appleton-Century-Crofts, 1955.

- Design for a research project on international conflict and the factors causing their aggravation or amelioration, Western Political Quarterly, 1957, 10, 263-75. 